\title{
Rationally Designed Synthetic Vectors for Gene Delivery
}

\author{
Gururaj Rao, Preeti Yadava and Jeffrey Hughes*
}

Department of Pharmaceutics, University of Florida, Gainesville, Fl, USA

\begin{abstract}
Vector development is one of the most important challenges facing the successful use of genes for treatment of diseases. Although chemically produced vectors offer distinct advantages over biological systems such as viruses, there are still some hurdles that have to be overcome before synthetic gene delivery vectors can be successfully implemented. This brief review discusses the biological barriers that limit current delivery strategies and reviews currently employed strategies for plasmid delivery. Nanoparticle-based gene delivery is reviewed along with methods for their characterization, physiochemical properties and toxicity. Finally a prospectus is provided for future development of an ideal synthetic gene delivery vector.
\end{abstract}

\section{GENE THERAPY}

Gene therapy involves the use of exogenous DNA as the therapeutic agent. Originally it was targeted towards treatment of inheritable single-gene disorders caused due to an absent or defective gene. However, applications of gene therapy have expanded to include treatment of acquired and infectious diseases and exogenously administered genes now are used in a wide variety of applications including immunomodulation, genetic vaccination and genetic pharmacology [1-6].

\section{THE GENE DELIVERY PROCESS}

Central to the success of any gene therapy is the efficient delivery of therapeutic genes to the target cell nucleus. In order to achieve this, the DNA, after being introduced into the body has to remain intact while it is carried by the circulatory system to the target tissue and the target cell (Fig. 1).

The complexity of delivering exogenous DNA becomes apparent when we consider the properties of DNA. Plasmid DNA (which is the workhorse in majority of gene therapy protocols) is large in terms of both molecular weight and size, the phosphodiester bond is a ready substrate for degradation by nucleases (which are abundant both in serum and inside the cell) and at physiological $\mathrm{pH}$, it's polyanionic nature (due to the phosphate backbone) prevents any spontaneous interaction with the negatively charged cell membrane. Thus, although delivery of naked (uncomplexed) DNA has met with success under certain scenarios, the majority of approaches favor the use of gene delivery agents or "vectors".

\section{NEED FOR NANOPARTICULATE DNA CARRIERS}

Based on the properties of DNA mentioned above, it appears that DNA delivery would be nearly impossible to accomplish. However, such a delivery system is already present in nature. Indeed, the virus is Nature's nanoparticle that has an exceptional ability to deliver exogenous DNA into the cell nucleus. A major effort in developing gene delivery systems has focused on the use of modified viruses. In this case,

*Address correspondence to this author at the Department of Pharmaceutics, University of Florida, Gainesville, Fl, USA;

E-mail: hughes@cop.ufl.edu the virus has to be gutted and genetically manipulated such that it cannot replicate, be infectious and does not elicit any severe immunological response. Viruses used as gene delivery vectors include retroviruses, adeno-viruses, adenoassociated viruses, herpes simplex virus, influenza virus and hepatitis B virus [8-12]. Attempts at designing virus-based vectors have been very successful considering the complexity of the problem, thanks to the advances in molecular biology. Viral constructs possessing high transduction efficiencies have been developed and utilized in clinical trials. However, even presently, there are concerns regarding toxicity. These concerns have been highlighted recently by a couple of unfortunate incidents during clinical trials with viralbased vectors $[13,14]$. The recent case of a young boy developing leukemia after being treated using a retroviral vector brings forth another concern, which is the possibility of insertional mutagenesis. Thus, it appears that despite the excellent transduction properties of viruses, toxicity problems still plague the field.

\section{NON-VIRAL DNA CARRIERS}

The experience with viruses has, of course, allowed us an insight into the necessary characteristics of a gene delivery system and has tremendously helped researchers who have long tried to develop non-biological alternatives to the virusbased approach. The research has resulted in a host of DNA carriers (both natural and synthetic) that have been designed to overcome one or several of the barriers mentioned above. Most of these carriers formulate DNA into discrete particles in the nano- to sub-micron size range. This size range is ideal as it permits efficient uptake into the cell via the process of endocytocis. Compaction of DNA also reduces its access to nucleases, which means that the transgene has a better chance of reaching the cell intact. In addition, many of the carriers impart an excess positive charge on the surface of the particles. This promotes interaction between the particles and cell surface and thereby aids in cellular uptake.

The path from the cell surface to the nucleus is another barrier to gene delivery. In most cases, cellular uptake of nanoparticles is via the endocytotic process. In order to reach the nucleus intact, the DNA nanoparticle has to escape from the endosome into the cytoplasm, traverse across the cytoplasm before it can enter the nucleus. If the nanoparticles cannot escape into the cytoplasm during the endosome stage, 


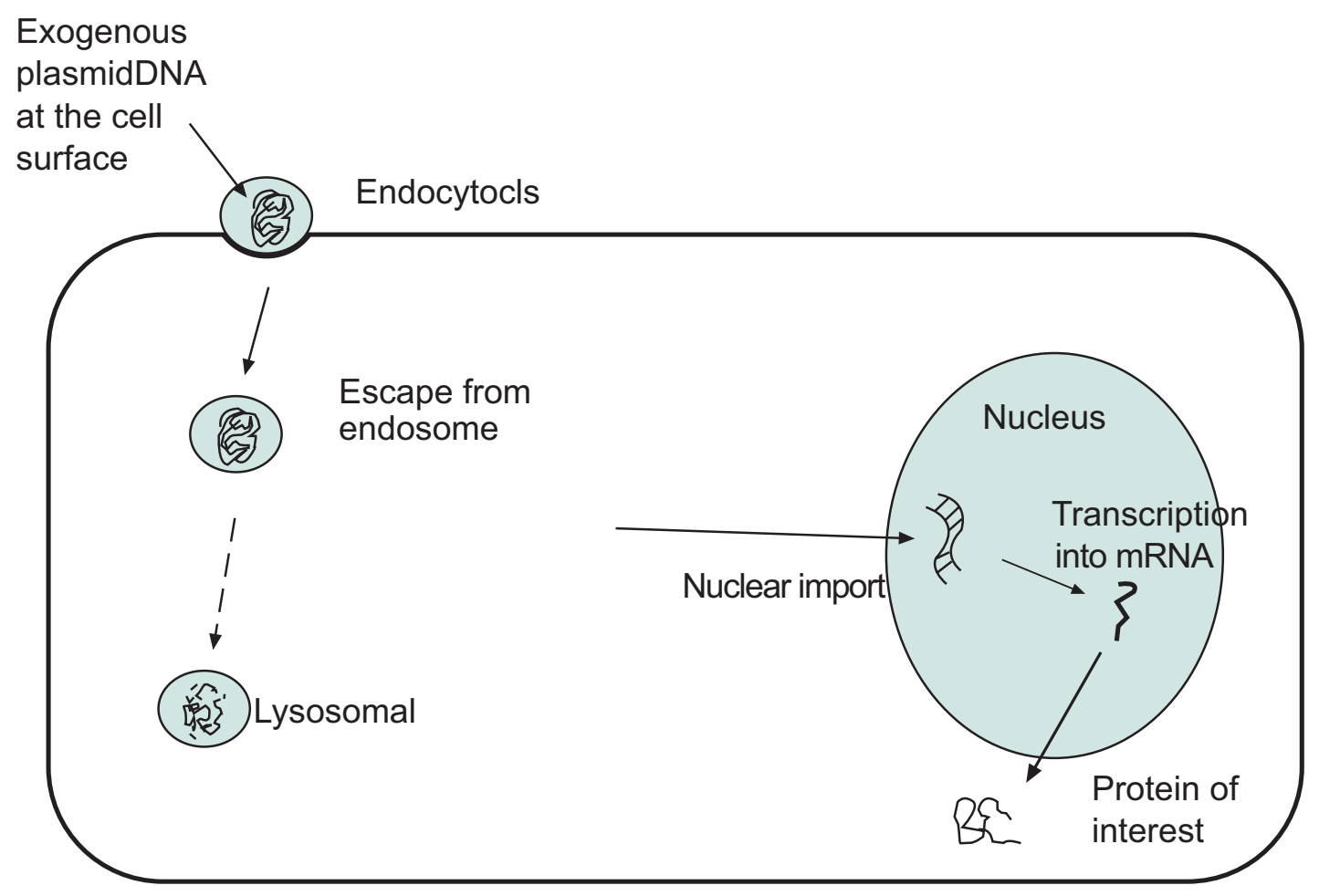

Fig. (1). Steps in the gene delivery process.

the DNA will eventually get degraded when the endosome matures into the lysosome. Thus, escape from endosomes is one of the major steps for gene delivery using non-biological nanoparticles. Several different approaches have been used to improve this step, ranging from using endosomolytic agents such as chloroquine to using $\mathrm{pH}$-sensitive lipids and polymers [15-18].

A host of different nanoparticulate carriers have been used for gene delivery. These include ceramic and metal nanoparticles, liposomes, polymeric nanoparticles and dendrimers. The types of application in which the nanoparticles are used vary. In some cases, the DNA is coated on the nanoparticle, in other cases, the DNA is entrapped inside the nanoparticle and yet in other cases, the transfection agent condenses DNA into a nanoparticle.

\section{CHARACTERIZATION OF NANOPARTICLES FOR GENE DELIVERY}

Nanoparticles for gene delivery are routinely evaluated on two levels: their physical characteristics (viz., size, surface charge, interaction of carrier with DNA) and their biological characteristics (for example: toxicity, transfection potential). Several different techniques including UV absorption, circular dichroism, isothermal titration, differential scanning calorimetry and IR spectroscopy have been used to characterize lipoplexes, polyplexes and secondary structure of DNA in these complexes. Dynamic light scattering (DLS) is the most popular method to estimate the mean hydrodynamic radius of suspended particles and their polydispersity index. DLS covers a size range from around 30 nanometers to several $\mu \mathrm{m}$ [19-21]. Light scattering methods are more sensitive as they detect the $90^{\circ}$-scattering, which can be measured either under steady-state conditions in a fluorime- ter or dynamically in a designated instrument equipped with a laser. The latter method, also called quasielastic light scattering or photon correlation spectroscopy (PCS), analyzes the intensity of the scattered light in the millisecond time regime through autocorrelation analysis. The Brownian motion of the particles induces a broadening of the spectrum that is related to their size and shape [22]. Particle size and structure of nanoparticles is also commonly evaluated using electron microscopy. Different methods of EM including negative-stain EM (for simple particle distribution), freezefracture (for studying membrane topology and geometry) and cryo-EM (for three-dimensional geometry and DNA load of vesicles) have been used to study both particle size and structural characteristics of lipoplexes and polyplexes [23-25]. Surface charge is conveniently measured using microelectrophoresis which provides the $\zeta$-potential. For most transfection applications, nanoparticles have positive $\zeta$ potentials. Extent of DNA condensation is usually evaluated using agarose gel electophoresis. The free DNA migrates freely through the gel toward the positive electrode; condensed DNA, on the other hand, does not migrate and stays in the loading well. Dye exclusion is another method to determine the condensing capacity of DNA carriers. DNA condensation occurs as the ratio of carrier to DNA increases. When DNA gets condensed it excludes intercalating dyes such as ethidium bromide resulting in a lower fluorescence levels compared to uncomplexed DNA. Thus, as ratio of carrier to DNA increases, the levels of fluorescence decrease (Fig. 2).

\section{APPROACHES TO GENE DELIVERY}

Gene delivery has been attempted using mechanical/ physical approaches (such as particle bombardment, electro- 
poration and sonoporation) where the DNA-nanoparticle is introduced directly into the cell either by force or by modulating the permeability of the cell membrane. In the other non-viral approaches (such as cationic lipid and polymeric carriers), the nanoparticulate vectors enhance uptake of DNA usually by promoting endocytocis. The different modes of delivery can also be used in combination - for example the particles drawn to the target cell using magnetic force and the polymeric or lipidic carriers promoting endocytocis.

N/P ratio: $0,0.3,0.6,0.9,1.2,1.5,1.8,2.1,2.4,2.7,3$
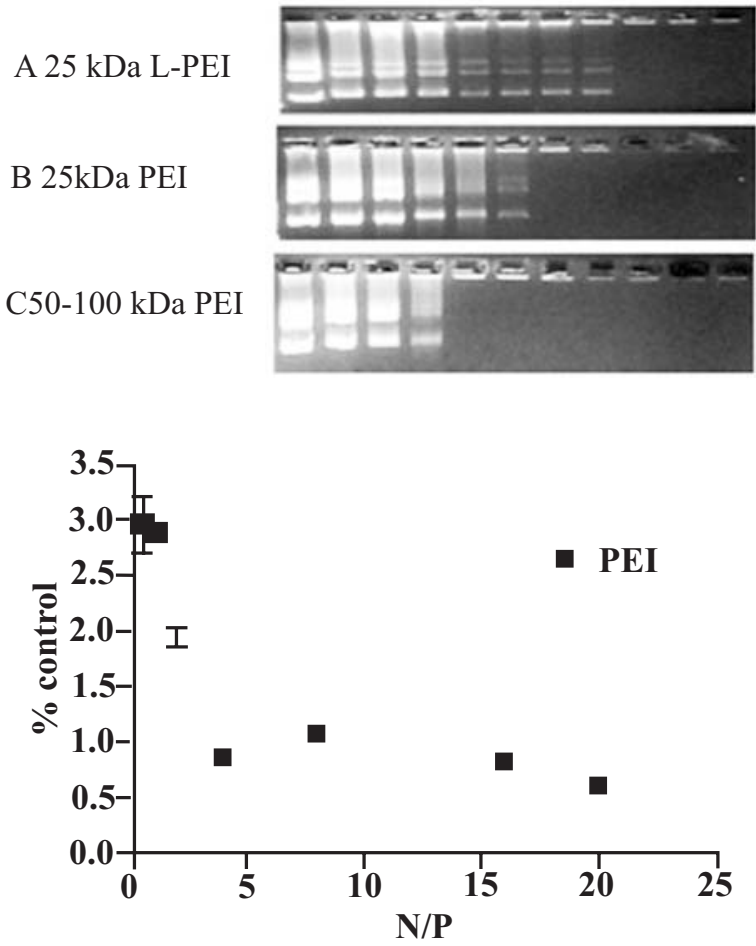

Fig. (2). Methods to evaluate extent of DNA-polymer interaction. A. Agarose gel electrophoresis of polyplexes using different polyethylenimines [7]. B. Ethidium bromide exclusion assay with polyplexes using branched PEI $25 \mathrm{kDa}$.

\section{Particle Bombardment or “Gene Gun” Approach}

In this approach, DNA is coated on the surface of metallic particles (most commonly, gold), which are propelled into the cell using a ballistic device (gene gun). This technique, first used for delivering genes into plants, is now very popular in genetic immunization protocols. In the original method, gunpowder was used to accelerate the DNA-coated tungsten particles through the plasma membrane; currently acceleration is achieved by a high-voltage electric spark or helium discharge. This approach is limited by accessibility to the target site - the most common application has been gene delivery to the skin [26]. Moreover, gene expression levels using the gene gun approach are usually localized and transient, which limit their use for gene-replacement purposes [27]. However, this approach has been found to be particularly useful for DNA vaccination [28]. Strong immune response has been obtained after epidermal delivery of as little as $16 \mathrm{ng}$ of DNA, which is 5000 times lower than that required with intramuscular or intradermal delivery [29]. The particles are usually 1-1.5 $\mu \mathrm{m}$ in size; however, there have been successful DNA vaccination studies using DNA-coated nanoparticles [30, 31]. Cationic nanoparticles $(<100 \mathrm{~nm})$ were prepared from oil-in-water $(\mathrm{O} / \mathrm{W})$ microemulsion precursors, comprised of emulsifying wax as the oil phase and CTAB (cetyltrimethylammonium bromide) as the cationic surfactant. DNA coated on these nanoparticles was used for genetic immunization in mice resulting in significant enhancements in humoral, Th1-type, and proliferative immune responses over 'naked' pDNA after both topical and subcutaneous administration.

\section{Lipid, Surfactant and Polymer-Based DNA Carriers}

The largest group of gene delivery agents is those based on carriers that condense DNA into nanoparticles and assist in the endosomal uptake. These carriers are mostly cationic and interact with the negatively charged phosphate backbone of DNA. Currently, there are two main classes of chemistrybased gene delivery agents, one based on the use of cationic lipid or liposomes (lipofection) and the other based on the use of cationic polymers (polyfection).

\section{Liposomes and Cationic Lipid-Based Vectors}

Liposomes were first proposed as a unique drug delivery system in the late 1960's by A.D. Bangham. DOTMA (N-[1(2, 3-dioleyloxy) propyl]-N,N-trimethylammonium chloride) (Fig. 4A) was the first synthetic cationic lipid to be used as a gene delivery vector in 1987 by Felgner et al. [32, 33]. Since then liposomes and cationic lipid/DNA complexes, also known as cationic lipoplexes [34], have become a popular technique in gene delivery.

Chemically cationic lipids are made up of a positively charged head group linked to a hydrophobic tail via a linker functional group (Fig. 3).

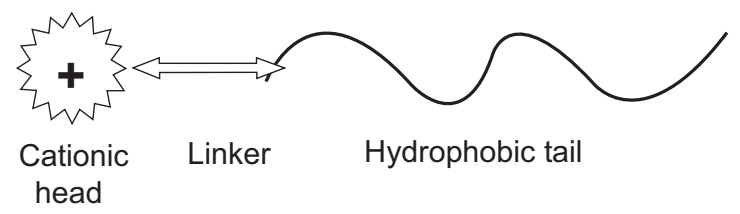

Fig. (3). Structural organization of a cationic lipid DNA carrier.

Lipids for gene delivery may be classified on the basis of their head, hydrophobic tails or linker functional groups (Tables 1-3). Head groups include quaternary ammonium salt lipids, lipoamines (primary, secondary, tertiary amines), combination of both and various other groups. Linkers are usually ethers or esters, but amides, carbamates and disulfides have also been used. Tail groups usually consist of cholesteryl groups or saturated or unsaturated alkyl chains (1218 carbons in length) [35]. DC-Chol was the first cationic lipid used for clinical trials. Extensive reviews have covered the various published structures and the different aspects of structure/activity relationships of cationic lipids [35, 54]. Lipoplexes have been reported to be very heterogeneous not only in terms of their size and composition but also their shape. Several techniques have been developed to characterize lipoplexes, such as X-ray diffraction and electron microscopy (EM). Huang et al. used freeze fracture EM and reported that DNA/DC-Chol/DOPE complexes were composed of tubular spaghetti like or a combination of spaghetti like and multilamellar meatball-like structures [55]. Recent $\mathrm{X}$-ray diffraction analyses have revealed DNA and cationic 
Table 1. Classification of Lipids on the Basis of Cationic Head Group

\begin{tabular}{|c|c|c|c|}
\hline Head Group & & Examples & Ref. \\
\hline \multirow{7}{*}{ Quaternary ammonium salts } & \multirow{3}{*}{ Monovalent } & cetyl trimethylammonium bromide (CTAB) & [36] \\
\hline & & $N$-[1-(2,3-dioleyloxy) propyl]- $N, N, N$-tri-methylammoniumchloride (DOTMA) & [33] \\
\hline & & 1,2-diacyl-3-trimethylammonium propane (DOTAP) & [37] \\
\hline & \multirow{4}{*}{ Polyvalent } & dioctadecylamidoglicylspermin (DOGS or "transfectam") & [38] \\
\hline & & DOSPA & [39] \\
\hline & & DPPES & [40] \\
\hline & & $\left(\mathrm{C}_{8}\right)_{2}$ Gly Sper ${ }^{3+}$ and $\left(\mathrm{C}_{18}\right)_{2} \mathrm{Sper}^{3+}$ & [41] \\
\hline $\begin{array}{l}\text { Aminoglycoside and aminoglycoside- } \\
\text { derived cationic lipids }\end{array}$ & & kanachol (3b-[6k-kanamycincarbamoyl] cholesterol) & [42] \\
\hline Pyridinium & & 1-(1,3-dimyristoyloxyprop-2-yl)-2,4,6-trimethylpyridinium & {$[43,44]$} \\
\hline
\end{tabular}

Table 2. Classification of Lipids on the Basis of Hydrophobic Tail

\begin{tabular}{|l|l|c|c|}
\hline Hydrophobic Tail & & Examples & Ref. \\
\hline \hline \multirow{3}{*}{ Single/double tailed } & single-tailed & CTAB, OLON, LHON and C14-CO & {$[45,46]$} \\
\cline { 2 - 5 } & double-tailed & DOTMA, DOGS and DOTAP & {$[33,47]$} \\
\cline { 2 - 5 } & \multirow{2}{*}{ Cholesterol } & Cholesteryl-3ß-carboxyamidoethylenedimethylamine (DC-Chol) & {$[48]$} \\
\cline { 3 - 5 } & & cholesten-5-yloxy- $N$-(4-((1-imino-D-thiogalactosyl-ethyl)amino)butyl)formamide (Gal-C4-Chol) & {$[49]$} \\
\hline
\end{tabular}

lipids to form very well-organized multi-lamellar structures with DNA sandwiched between the lipid bilayers [56].

Table 3. Classification of Lipids on the Basis of Linker

\begin{tabular}{|c|c|c|}
\hline Linker Functionality & Examples & Ref. \\
\hline \hline Esters & DOTAP & {$[47]$} \\
\hline Ethers & DOTMA & {$[33]$} \\
\hline Amides & DOGS & {$[38]$} \\
\hline Glycosidic & & {$[50]$} \\
\hline Oxyethylene & & {$[51,52]$} \\
\hline Disulfide & QS3, DOGSDSO & {$[53]$} \\
\hline
\end{tabular}

The stepwise mechanism for lipoplex entry into a cell via endocytosis followed by release due to destabilization of the endosomal membrane was first proposed by $\mathrm{Xu}$ et al. [57]. The complexes are generally believed to interact with cells through a non-specific charge interaction. A net positive charge ensures efficient binding to negatively charged cell surfaces. It has been proposed that due to the membranous structure of lipoplexes the complexes can directly penetrate the cell membrane through fusion with the membrane or lipid mediated poration, but it was shown that there is no correlation between the capability for fusion with the plasma membrane and transfection efficiency. Endocytosis is believed to be the common mechanism of uptake of synthetic cationic lipids by cells $[58,59]$. The escape of DNA from the endosome is thought to depend on the ability of some lipids to form a fusogenic inverted hexagonal phase [60, 61]. It has also been proposed that cationic lipids can destabilize lipid bilayers by promoting the formation of nonbilayer structures such as the inverted hexagonal (HII) phase [62-64]. An additional factor that may play an important part in the escape of the DNA from the endosome is the increase in osmotic pressure in the endosome.

We have shown disulfide linker containing lipids N', N', N'-trimethylaminoethyl-1'-cholesteryl-3, 3'-dithiodipropionamide (QS3) (Fig. 4C) and 1,2-dioleoyl-sn-glycero-3-succinyl-2-hydroxyethyl di-sulfide ornithine conjugate (DOGSD SO) (Fig. 4D) to be more efficient than their non-disulfide containing counterparts QN3 (N', N', N'-trimethylaminoethyl-8-cholesteryl-1-suberamide) (Fig. 4C) and DOGSHDO (1,2-dioleyl-sn-glycero-3-succinyl-1,6- hexanediol ornithine conjugate) (Fig. 4D). DOGSDSO was shown to be more efficient than DOTAP/DOPE liposomes in three cell lines [65].

Modifications of the cationic lipid hydrophobic tail are also not uncommon. Single tailed cationic lipids were reported to have low transfection efficiency and high toxicity [45]. We synthesized a single-tailed cationic lipid-oleoyl ornithinate (OLON) (Fig. 4E). To decrease cytotoxicity, we then introduced a potential biodegradable ester bond in the tail of lipid yielding 6-lauroxyhexyl ornithinate (LHON) (Fig. 4E). We demonstrated that the cytotoxicity of LHON was lower than that of 1,2-dioleoyl-3-trimethylammoniumpropane (DOTAP) (Fig. 4F) or OLON. OLON/DOPE had more than 10 times the transgene expression than other liposomes even though the DNA uptake was not necessarily greater. A greater fraction of DNA was released from DNA/ OLON/DOPE complexes than that from DNA/DOTAP/ DOPE complexes by dextran sulfate and sodium dodecyl sulfate. 
A

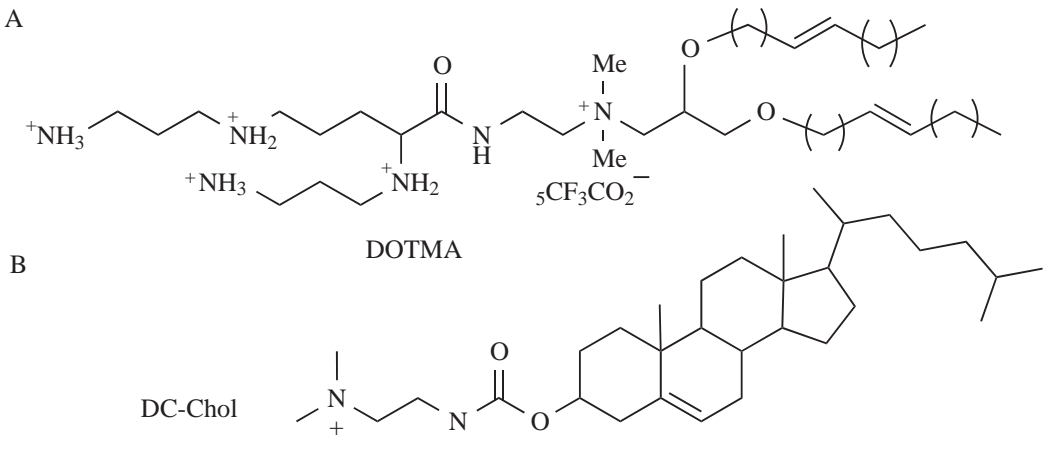

c

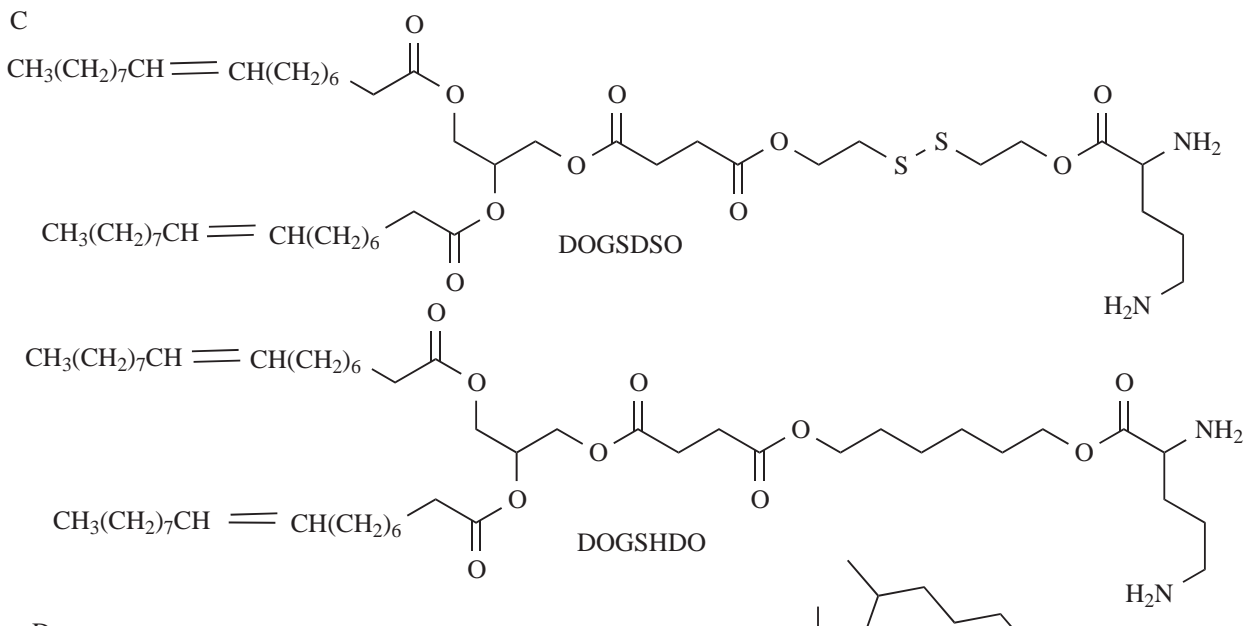

D<smiles>CC(C)CNC(=O)CCCCCCC(=O)OC1CCC2(C)C(=CCC3C4CCCC4(C)CCC32)C1</smiles>

E<smiles>CCCCCCCC/C=C/CCCCCCCOC(=O)C(N)CCCN</smiles>

F

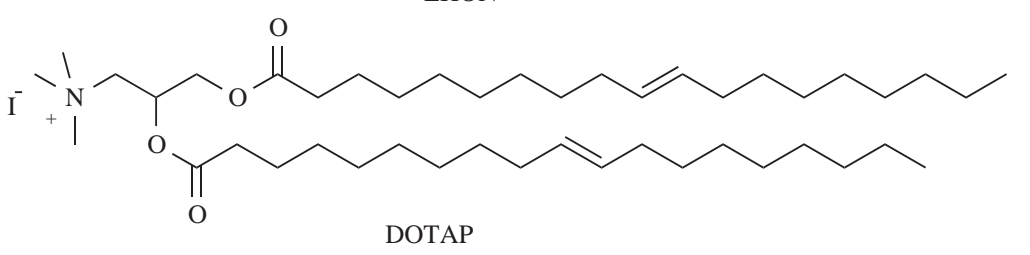

Fig. (4). Cationic lipids for gene delivery. 
Chemical structure of cationic lipids can greatly influence the transfection ability of lipoplexes. The transfection potency of cationic lipids has been found to decrease with increasing lipid saturation. This is considered to be due to their enhanced ability to promote non bilayer structure in the presence of negatively charged cellular phospholipids [66]. Cationic liposomes are often formulated with a helper lipid e.g. cholesterol, unsaturated phophatidylethanolamines such as dioleoylphosphatidylethanolamine (DOPE) [67]. The helper lipids are known to stabilize the liposomal bilayer and promote fusion. Inverted hexagonal phase can be induced by the shape of the cationic detergent [68] or of the helper lipid [69], or by the interaction of the lipoplex with anionic lipids [66].

It has been observed that levels of gene expression and the organs showing maximum levels of gene expression differ depending upon the lipid used. Gene expression in the liver has been shown to increase significantly when DOTIM: Cholesterol (1: 1 molar ratio) multilamellar vesicles are injected intravenously. Liu et al showed that all of the internal organs including lung, liver, spleen, heart and kidney expressed the transgene upon systemic administration of $1.25 \mathrm{mg} / \mathrm{kg}$ plasmid DNA complexed with DOTMA-Tween 80 lipid formulation [70]. It was also demonstrated that gene expression increased in all organs upon increasing the dose of plasmid DNA from $1.25 \mathrm{mg} / \mathrm{kg}$ to $5 \mathrm{mg} / \mathrm{kg}$.

\section{Formulation of Liposomes}

Multi lamellar vesicles (MLV) are usually prepared by dissolving the lipids (cationic and helper) in an organic solvent such as chloroform followed by removal of the organic solvent to yield a lipid layer which when hydrated under agitation results in a heterogeneous suspension of MLVs. These MLVs may then be sonicated to produce small unilamellar vesicles (SUV, 30-60 nm), extruded through a polycarbonate filter or homogenized to produce large unilamellar vesicles (LUV, 80-400 nm) [71]. Alternatively the lipids can be dissolved in ethanol or ether and injected into an appropriate buffer to form a heterogeneous mixture of MLV, SUV or LUV depending on the concentration of lipid. These methods can readily incorporate hydrophobic and amphiphilic drugs into the liposomes [72, 73]. For incorporation of water-soluble compounds liposomes can be passively charged using reverse phase evaporation (REV), dehydrated and rehydrated alternately, freeze-dried and rehydrated, or hydrated in the presence of a detergent which is later removed by dialysis or gel filtration [74]. Liposomes can also be actively loaded by varying the $\mathrm{pH}$ and ionic strength of the system.

It is well known that the concentrations of lipid and DNA, the ionic strength and temperature of the suspending medium, the order of addition, and the rate of mixing affect the resulting lipoplex size and homogeneity.

Since the lipid-DNA assembly is governed by multivalent electrostatic interactions, macroscopic aggregation tends to be kinetically controlled and irreversible, while thermodynamic equilibrium can only be locally established at the microscopic level [75]. It is not surprising that different transfection activities have been reported for any given liposome composition, depending on the use of MLV, LUV or SUV.

\section{Formulation Parameters}

Several factors can influence the transfection capability of a nucleic acid/lipid complex. These include size and shape of the complex, nature of lipids, presence of helper lipids, targeting agents. Although the relationship between the size and shape of the lipoplexes, their cell uptake potential and the chemical structure of the condensation agents is not clear, size of the transfection reagent /DNA complex has been reported to influence receptor-mediated endocytosis (RME), opsonization, circulatory half life, migration through the endothelial cells, movement after injection into solid tissues and nuclear entry mechanism [76, 77]. Diffusion across the nuclear pore complex (diameter: $25-55 \mathrm{~nm}$ ) is a possibility for particles smaller than $25 \mathrm{~nm}$. However, nuclear entry of particles up to $39 \mathrm{~nm}$ has been reported, which is probably dependant on interactions with the nuclear pore complex $[78,79]$. Smaller nanoparticles are taken up by cells more easily through RME, evade the immune system and can be targeted to particular tissue types.

Size and shape of the complex can in turn be influenced by several factors including the number of positive charges, charge density, polyamine structure, electrostatic interactions, ionic strength of the medium, number of positive charges of the counterions and DNA-solvent interactions. Diaminoalkanes with three and five methylene groups have been reported to be more effective than diamines with two, four, and six methylene groups [80].

Another school of thought is that the size the lipoplexes is mainly dependent on the cationic lipid/DNA charge ratio and not the composition of the lipid or the helper lipid [81]. $\mathrm{Xu}$ et al. showed that at neutral N/P ratio large aggregates $(>1 \mu \mathrm{m})$ are formed [81]. While at a positive N/P ratio, large multilamellar vesicles (LMV) $(300-700 \mathrm{~nm})$ are more efficient than the small unilamellar vesicles (SUV) $(50-200 \mathrm{~nm})$ $[82,83]$. The order in which DNA and lipid are mixed has also been suggested to influence size of the transfection complex [81, 84]. Addition of DNA to lipid results in slow increase in lipoplex size. The opposite order of mixing shows no change in the complex size until the N/P ratio becomes net positive, as a result of which the particle size increases rapidly [84]. Multivalent anions present in the serum or media can also facilitate fusion of the lipoplexes resulting in an increase in the size of the lipoplexes.

\section{Surfactants}

Several methods have been proposed for the production of small monodispersed transfection particles [85]. One such approach for condensing plasmid DNA into a small size is the use of cationic detergents with sulfhydryl groups, below their critical micelle concentration (CMC). The higher water solubility of detergents can result in fast DNA release, which contributes to lower transfection activity. It has been suggested that the surfactant-DNA complex be stabilized by dimerization of free sulfhydryl group on the nucleic acid backbone. This combines the advantages of cationic detergents and lipids [86]. Disulfide groups also allow release of DNA in the reducing environment inside the cell (Fig. 5A). One such thiol detergent $\mathrm{N}$-dodecyl-2-mercapto imidazole (DMI) (Fig. 5B) was synthesized by our group [87]. This detergent was shown to be able to form a disulfide bond when oxidized and the presence of polyanions significantly 
A
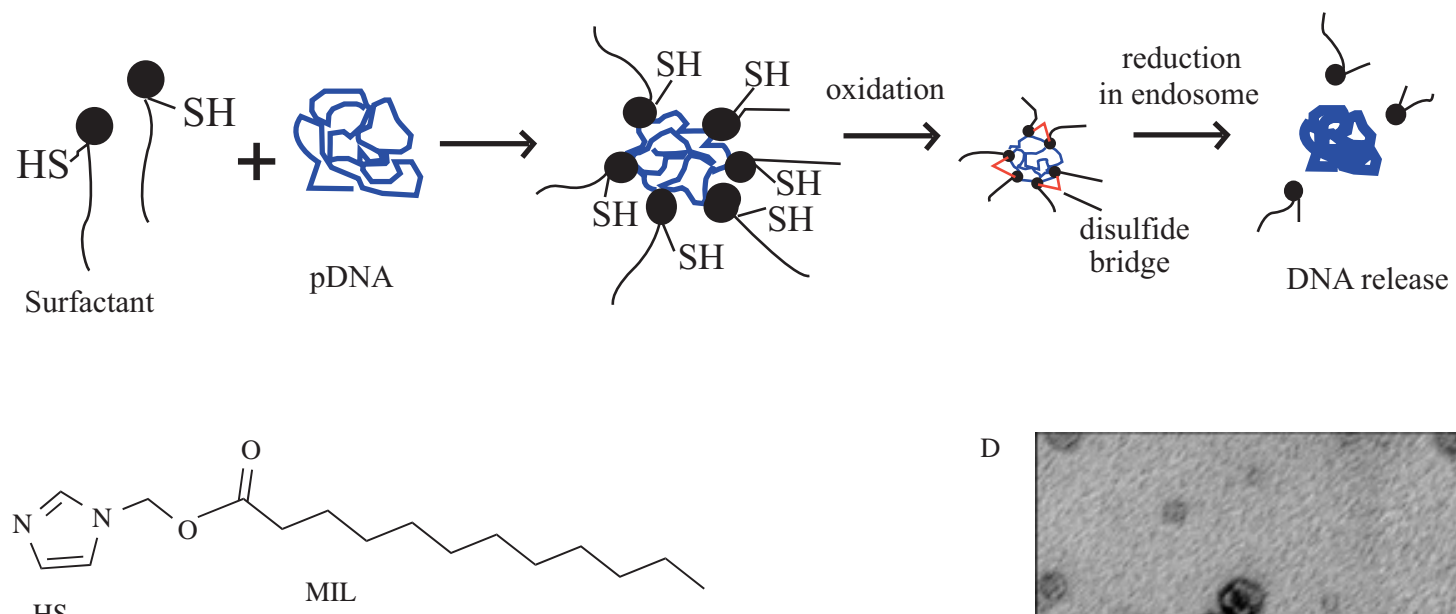

D<smiles>CCCCCCCCCCCn1ccnc1S</smiles><smiles>CCCCCCCCCCCCCCNC(=O)C(CS)NC(=O)C([NH3+])CCC</smiles><smiles>CCCCCCCCCCCCOC(=O)C(C)n1ccnc1</smiles>

Fig. (5). Surfactants for gene delivery. A. Schematic showing mechanism of action of cationic surfactants with reducible bonds. B. Ndodecyl-2-mercapto imidazole (DMI); C. C14-CO; D. Electron microscopy of monodispersed, virus sized particles formed upon interaction of DMI with pDNA. E. dodecyl 2-(1'-imidazolyl) propionate.

increased the rate of oxidation. The addition of a reducing agent disrupted the disulfide bonds initially, but the disulfide bonds were reformed after a short time period. The CMC values for DMI was around $1 \mathrm{mM}$ which is 10 times greater than the CMC value of the ornithine-cysteine based surfactants (C14-CO, Fig. 5C) reported by Behr et al. [88]. Electron microscopy shows formation of monodispersed, virus sized particles upon interaction of DMI with plasmid DNA (Fig. 5D). In addition to directly using surfactants for gene delivery, we have synthesized and used a $\mathrm{pH}$-sensitive surfactant dodecyl 2-(1'-imidazolyl) propionate (DIP) [89] (Fig. $\mathbf{5 E})$ to facilitate AAV-mediated gene-transfer to neurons and glia cells [90]. Addition of DIP increased maximum transfection efficiencies in glial and neuronal cultures by 2-3fold.

\section{Polymer-Mediated Gene Delivery}

Various cationic polymers (natural and synthetic) have been studied as potential DNA carriers (Fig. 6; Table 4). Early studies were conducted using naturally occurring polymers such as chitosan and proteins such as histones and cationized human serum albumin [91]. Other polymers used include polypeptides such as poly-L-lysine and poly-Lornithine, and polyamines such as polyethylenimine (PEI) and starburst polyamidoamine (PAMAM) dendrimers [9296]. Both linear and branched forms of polymers have been used. Several synthetic copolymers containing hydrophilic segments (such as polyethylene glycol, PEG or dextran) have also been evaluated [97-99].

Cationic polymers, like cationic lipids, interact with the anionic phosphate backbone of DNA and condense the plasmid into nano-scale particles $[100,101]$. The majority of cationic polymers are polyamines and the ratio of polymer to DNA is commonly expressed in terms of the concentration of amines from the polymer and the concentration of phosphates from DNA (the N/P ratio). The ratio of polymer to DNA needed for complete condensation of DNA varies with the polymer used and also with the molecular weight of the polymer. In most cases, DNA is completely condensed at N/P ratios of 2-3 forming polyplexes possessing slightly negative or close to neutral zeta potentials. However, most gene delivery protocols use higher N/P ratios $(>5)$ since that seems to improve transfection efficiencies. DNA nanoparticle formation and the size of the nanoparticles have also been shown to be influenced by the structure of isovalent polyamines $[102,103]$. Cobalt hexamine $\left[\mathrm{Co}\left(\mathrm{NH}_{3}\right) 63+\right]$ an inorganic cation that is nonreactive to DNA bases condensed DNA 5-fold more efficiently than spermidine $\left[\mathrm{H}_{2} \mathrm{~N}\left(\mathrm{CH}_{2}\right)_{3} \mathrm{NH}\left(\mathrm{CH}_{2}\right)_{4} \mathrm{NH}_{2}\right]$ with the size of the condensates generally smaller than that formed with spermidine [104]. Polyplexes formed at higher $\mathrm{N} / \mathrm{P}$ ratios tend to be in the range of $100-200 \mathrm{~nm}$ and possess an overall positive surface charge $(+20-40 \mathrm{mV})$. The excess positive charge on polyplex surface promotes association with the negatively charged cell membrane via electrostatic interaction with 
negatively charged heparin sulfate proteoglycan (HSPG) residues on the cell surface [105-107]. Recently, a model based on cell entry using syndecans, a class of transmembrane HSPGs, as receptors has been proposed. Binding of polyethylene-based polyplexes to syndecans leads to clustering of syndecans into cholesterol-rich rafts, which in turn triggers the internalization of polyplexes via the endocytotic pathway [108]. HSPGs are ubiquitously expressed on adherent cells - probably the reason for wide variety of cells that can be transfected using polycations. However, this advantage turns into a liability in vivo where polyplexes interact non-specifically with anionic components (discussed further below).

A

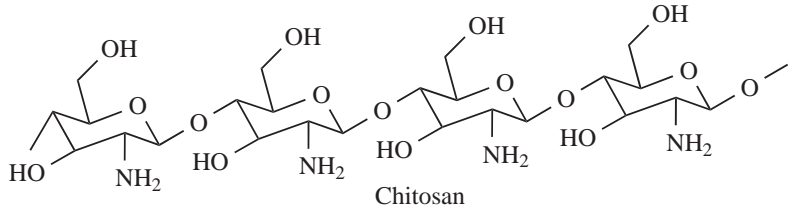

B<smiles>CC(C)(C)CN([Tl]C(=O)C(CCCCN)NC(=O)C(CCCCN)NC(=O)C(CCCCN)NC(=O)C(CCCCN)NC(=O)C(CCCCN)NC(C)(C)C)C(=O)NC(C)(C)C</smiles>

C

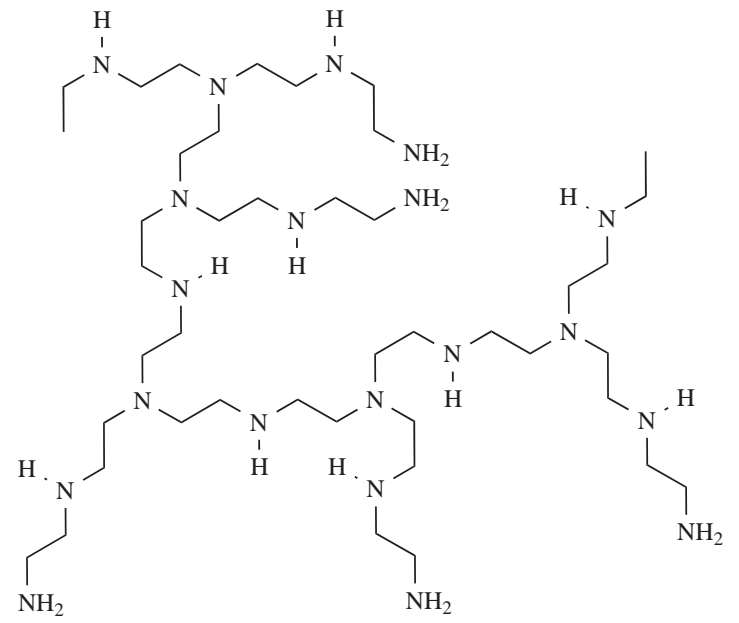

Fig. (6). Cationic polymers for gene delivery. A. Chitosan; B. polyL-lysine; C. branched polyethyleneimine.

Some of the polymers such as polyamidoamine (PAMAM) dendrimers and PEI possess a large buffering capacity over a wide range of $\mathrm{pH}$ due to a large number of secondary and tertiary nitrogens. The resulting "protonsponge effect" $[93,109,110]$ aids in escape of the polyplexes from the endosomes to the cytoplasm - a step that is considered to be one of the major barriers of gene delivery to the nucleus. These polymers are only partially protonated at physiological $\mathrm{pH}$; even after binding to DNA, only 1 to 3 nitrogens in PEI are protonated [111]. In the acidic environment of endosomes, the ability of the polymer to capture protons leads to osmotic swelling and endosomal disruption.
Table 4. Common Polymers Used in Gene Delivery

\begin{tabular}{|l|l|}
\hline \multicolumn{1}{|c|}{ Type of polymer } & \multicolumn{1}{c|}{ Ref. } \\
\hline \hline $\begin{array}{l}\text { Natural } \\
\text { Chitosan }\end{array}$ & {$[91]$} \\
\hline $\begin{array}{l}\text { Polypeptide } \\
\text { Poly-L-lysine }\end{array}$ & {$[142,143]$} \\
\hline $\begin{array}{l}\text { Polyethylenimines } \\
\text { Branched PEI } \\
\text { Linear PEI } \\
\text { PEI-polyethylene glycol conjugate } \\
\text { Pluronic-cationic polymer conjugates }\end{array}$ & {$[119-121]$} \\
\hline $\begin{array}{l}\text { Dendrimers } \\
\text { Polyamino } \\
\text { Polyamidoamino }\end{array}$ & {$[93,94,96,100,122,123,144]$} \\
\hline
\end{tabular}

Polyethylenimine has been found to be a very effective transfection agent both in vitro and in vivo. In our laboratory, we found that transfection efficiency of PEI varies with cell type, molecular weight and structure of the polymer. Linear PEI (25 kDa) was compared to branched PEI (25 $\mathrm{kDa}$ ) and high molecular weight PEI (50-100 kDa). We found that the branched form of PEI was more efficient at condensing DNA and results in smaller particles $(782 \mathrm{~nm}$ for linear PEI $v s 70 \mathrm{~nm}$ for branched PEI) at an N/P ratio of 8 . The transfection efficiency was dependant on cell type. Linear PEI had the best transfection efficiency in bronchial epithelial cells IB3-1. In glial cells, branched PEI (25 kDa) had higher transfection efficiency than linear PEI and PEI 50-100 kDa. In neuronal cells, the transfection efficiency was in the order PEI 50-100 < branched PEI < linear PEI. The higher molecular weight PEI showed high levels of toxicity when used at N/P ratios > 5 [7]. Linear PEI, however, has been found to be an effective transfection agent in vivo. PEI-mediated transfer of the nerve growth factor (NGF) gene into rat brain protected septal cholinergic neurons in a rat fimbria fornix lesion model. PEI transfection was predominantly in neurons as seen after GFP-gene transfer into the septum [112].

\section{BIOCOMPATIBILITY AND MODIFICATIONS TO REDUCE TOXICITY}

At the core of every new drug lies the all-important need to balance its efficacy and safety. Non-viral vectors certainly enjoy a higher degree of acceptance in terms of safety compared to viral vectors. However, that is not to say that nonviral vectors are without any toxicity. Toxicity can be attributed in some cases to the nature of the material used. Acute toxicity of polycationic carriers is associated with their ability to nonspecifically bind to negatively charged cell membrane and other biological materials. In addition, toxicity associated with the lack of biodegradability is a major concern with many synthetic polymer and lipid-based carriers a problem particularly when long-term fate of the carrier is considered. Therefore more biocompatible DNA carriers, 
which can be easily degraded in vivo, would be advantageous. Cationic lipids have been synthesized containing degradable linkers (such as ester, amide and carbamate linkages) connecting the hydrophobic and hydrophilic regions in order to lower toxicity. Although the introduction of the ester bond can increase biodegradability, it may also decrease the stability of liposomes in systemic circulation [113]. In our laboratory, we have synthesized a disulfide linker-containing cationic lipid (cholesteryl hemidithiodiglycolyl tris(aminoethyl) amine; CHDTAEA; Fig. 4G) that takes advantage of the high intracellular reductive environment [114]. This can decrease the toxicity while not sacrificing the stability of liposomes in aqueous media $[114,115]$. Such lipids are selectively stable outside cells, but once internalized can be reduced by intracellular reductive substances such as glutathione. The reduction of a disulfide linker will result in the collapse of complexes and enhance the release of DNA from DNA/liposomes complexes. This enhanced release of DNA from DNA/liposome complexes is expected to increase transgene expression. Compared to an analogue (cholesteryl $\mathrm{N}$-(dimethylaminoethyl) carbamate; DC-Chol) that did not contain a disulfide linker CHDTAEA resulted in significantly lower toxicity in $\mathrm{CHO}$ cells and also had more than 2 orders of magnitude higher gene expression compared to DC-Chol [114].

Biodegradable polymers have also been synthesized using low molecular weight polymers bound together with biodegradable linkers such as ester and disulfide linkages. A biodegradable ester analog of polylysine, poly[alpha-(4aminobutyl)-L-glycolic acid] (PAGA) resulted in lower toxicity compared to polylysine, but the ester bond made the polymer unstable in solution and thus lead to only a 2-fold increase in transfection efficiency [116]. Use of bioreversible disulfide bonds instead, provides optimal stability of the polymer while reducing in vivo toxicity. Biodegradable PEI and oligolysine polymers have been synthesized containing disulfide linkages [24, 117]. Several additional examples of biodegradable polycation gene carriers can be found in the literature, including for example block-copolymers with noncationic, hydrophilic polymers. However, several of the modified polymers show low transfection efficiencies. Recently a biodegradable polymer of a branched network of amino esters (n-PAE) with transfection efficiencies similar to PEI $25 \mathrm{kDa}$ but lower cytotoxicity was described [118]. The polymer was designed to possess a buffering capacity similar to PEI - thus leading to the proton sponge effect in the endosome. The network structure of the polymer is based on polycondensation of TRIS molecules N-disubstituted with methyl acrylate, and terminal amino groups were attached to the polyester condensate in form of 6-amino hexanoic acid esters. This structure provides multiple ternary and primary amines for DNA binding and endosomal buffering. The network structure is also important to control the rate of polyester degradation. n- PAE displays medium stability, while linear amino-modified polyester appears to show too fast hydrolysis rates. Polymers such as n-PAE fulfill the two main requirements, efficient transfection and low toxicity, and should be useful in the future. Cationic polymers have also been used in conjuction with ampiphillic Pluronic $\AA$ copolymers, which consist of poly-ethylene oxide (PEO) and poly-proplylene oxide (PPO) repeats. Conjugation of cationic polymers such as polyethylenimine or poly[2dimethylamino ethyl methacrylate] (pDMAEMA) with Pluronic ${ }^{\circledR}$ copolymers has been shown to improve transfection efficiencies and decreased toxicity [119-121].

Another approach to reducing toxicity of lipoplexes and polyplexes is to shield the surface of the nanoparticles with hydrophylic polymers such as polyethylene glycol (PEG). This shielding neutralizes the surface charge and also reduces non-specific interactions of the nanoparticles with the cell membrane and other positively charged macromolecules in vivo. Several groups, including ours, have observed lower toxicity with "PEGylated" polyplexes [122, 123]. Polyplexes modified with PEG have reduced non-specific interactions and improved circulation times in vivo. Under certain conditions addition of a hydrophilic shielding agent could result in lowered transfection efficiency. This problem can be overcome by using targeting ligands incorporated into the DNA nanoparticles.

\section{Targeting of Nanoparticles}

Targeting has always been a major part of developing vectors for gene delivery. In general, it is better that the gene uptake occurs only in cells that need it, especially so in case of cancer gene therapy in which cytotoxic or pro-apoptotic genes are introduced. Targeting can be achieved either passively through the Enhanced Permeation and Retention (EPR) effect or actively by functionalizing the vector with targeting ligand for a particular cellular receptor. In addition to the above methods, there are other physical methods of targeting such as magnetofection and photosensitive or heatsensitive carriers.

In many cases, the two or more approaches to targeting can be used in sync. For example, when targeting a distant tumor, the nanoparticle can preferentially concentrate in the tumor due to EPR and the targeting ligands can confer a second degree of specificity such that the particles are specifically taken up by cancer cells via a selective receptor and not by the neighboring healthy cells. There are several examples of targeted (both passive and active) gene delivery. This concept was introduced earlier in liposomes and the socalled "stealth liposomes" have been useful in increasing the in vivo circulation half-lives of both small molecules and macromolecules [124-130]. This concept has also been applied in conjunction with polymeric DNA carriers [131-133]. Shielding ligands can be introduced into the polyplexes at various stages of polyplex formation. Modifying the cationic polymer before condensation with DNA offers better control over the degree of modification and also allows us to characterize the modified polymer. However, pre-modification of the polymer may interfere with the basic function of the polymer leading to poor DNA condensation and reduced transfection efficiencies $[111,134,135]$. Alternatively, PEGylation can be performed subsequent to polyplex formation. Although this approach circumvents the problem of interference with DNA condensation, it could be inconvenient for routine use [136, 137]. In many cases PEGylation is used in conjunction with active targeting ligands. This "shield and target" approach has been used successfully deliver DNA to specific sites such as the liver, brain, lung and tumors. 


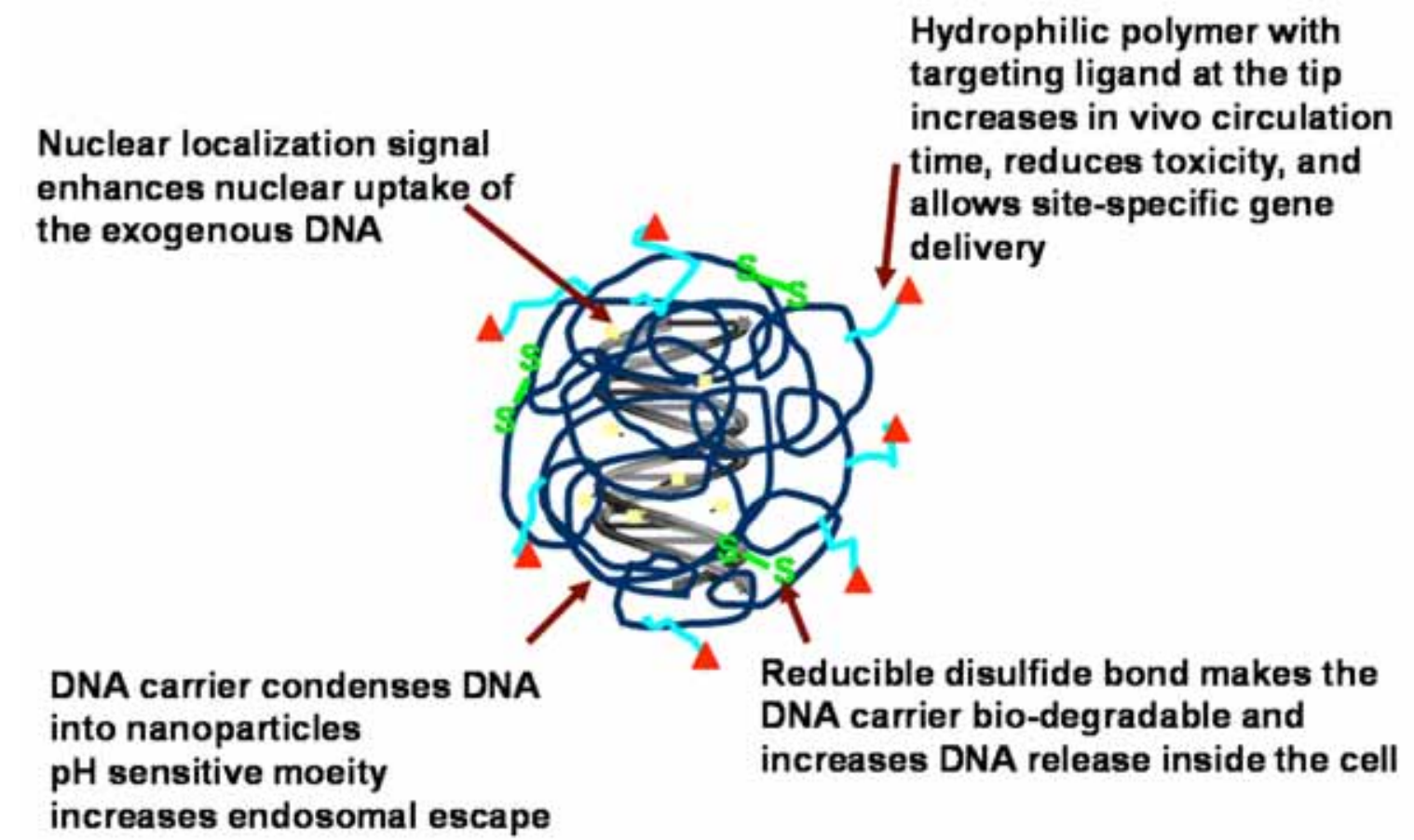

Fig. (7). Artificial virus. The gene delivery vector with multiple functionalities to increase efficacy and improve safety.

\section{THE IDEAL VECTOR}

Several years of research have lead to enormous advances in the design of a gene delivery vector. Both viral and non-viral constructs have been successful, but both these systems also have their own disadvantages. In terms of clinical application, the majority of clinical trials currently approved use viral vectors (http: //www.wiley.co.uk/genetherapy/clinical/). Cinical applicability of cationic lipid and polymer-based nanoparticles is still limited by their low in vivo transfection efficiencies compared to viral vectors. Toxicity at high doses is also a concern. Current research is thus focused on developing gene delivery non-viral vectors with optimum safety and efficacy. The gene delivery approach and the vector(s) used will depend on the application. Complex synthetic gene delivery vectors are now being designed with each step of the delivery process in mind (Fig. 7).

Today's DNA carrier is designed to accomplish more than just condense DNA into nanoparticles [138]. In addition to condensation, the nanoparticle is imparted with multiple functionalities that address the various factors affecting the gene delivery process. The carriers themselves are more biofriendly and less toxic. In addition, shielding agents increase in vivo circulation times and lower toxicity related to nonspecific uptake of the nanoparticles. The shielding also permits passive targeting of the nanoparticles. Active targeting to a specific site has been attempted by incorporating organ/cell-specific targeting ligands. Once inside the cell, inclusion of fusogenic peptides can improve endosomal transfer. Alternatively, the complex can include the so-called cellpenetrating peptides, which have been observed to facilitate efficient transfer of macromolecules into the cell cytoplasm $[139,140]$. The endosomal escape step has already been addressed by including $\mathrm{pH}$-sensitive lipids and polymers. The nuclear transfer step can be addressed by including nuclear localization signals in the DNA itself. Finally, an additional layer of targeting can be achieved by using tissue/ cellspecific gene promoters [141]. As we understand the gene delivery process more clearly, so will we be able to improve the design of DNA nanoparticles.

\section{ACKNOWLEDGEMENTS}

The authors would like to gratefully acknowledge the financial support of NIH grant P01-AG10485.

\section{REFERENCES}

[1] Strayer DS, Akkina R, Bunnell BA, et al. Current status of gene therapy strategies to treat HIV/AIDS. Mol Ther 2005; 11: 823-42.

[2] Morishita R, Aoki M, Ogihara T. Does gene therapy become pharmacotherapy? Exp Physiol 2005; 90: 307-13.

[3] Chen HK, Hung HF, Shyu KG, et al. Combined cord blood stem cells and gene therapy enhances angiogenesis and improves cardiac performance in mouse after acute myocardial infarction. Eur J Clin Invest 2005; 35: 677-86.

[4] Yechoor V, Chan L. Gene therapy progress and prospects: gene therapy for diabetes mellitus. Gene Ther 2005; 12: 101-7.

[5] Kofron MD, Laurencin CT. Orthopaedic applications of gene therapy. Curr Gene Ther 2005; 5: 37-61.

[6] Nathwani AC, Davidoff AM, Linch DC. A review of gene therapy for haematological disorders. Br J Haematol 2005; 128: 3-17.

[7] Zhang C, Yadava P, Hughes J. Polyethylenimine strategies for plasmid delivery to brain-derived cells. Methods 2004; 33: 144-50.

[8] Suter SE, Gouthro TA, O'Malley T, et al. Marking of peripheral Tlymphocytes by retroviral transduction and transplantation of CD34(+) cells in a canine X-linked severe combined immunodeficiency model. Vet Immunol Immunopathol 2007.

[9] Vaha-Koskela MJ, Heikkila JE, Hinkkanen AE. Oncolytic viruses in cancer therapy. Cancer Lett 2007.

[10] Ng CJ, Bourquard N, Hama SY, et al. Adenovirus-Mediated Expression of Human Paraoxonase 3 Protects Against the Progression of Atherosclerosis in Apolipoprotein E-Deficient Mice. Arterioscler Thromb Vasc Biol 2007.

[11] Osten P, Grinevich V, Cetin A. Viral vectors: a wide range of choices and high levels of service. Handb Exp Pharmacol 2007; 178: 177-202.

[12] Kasuya H, Takeda S, Shimoyama S, et al. Oncolytic virus therapy-foreword. Curr Cancer Drug Targets 2007; 7: 123-5. 
[13] Gansbacher B. Report of a second serious adverse event in a clinical trial of gene therapy for X-linked severe combined immune deficiency (X-SCID). Position of the European Society of Gene Therapy (ESGT). J Gene Med 2003; 5: 261-2.

[14] Lehrman S. Virus treatment questioned after gene therapy death. Nature 1999; 401: 517-8.

[15] Guy J, Drabek D, Antoniou M. Delivery of DNA into mammalian cells by receptor-mediated endocytosis and gene therapy. Mol Biotechnol 1995; 3: 237-48.

[16] Haas DH, Murphy RM. Design of a pH-sensitive pore-forming peptide with improved performance. J Pept Res 2004; 63: 9-16.

[17] Kyriakides TR, Cheung CY, Murthy N, Bornstein P, Stayton PS, Hoffman AS. pH-sensitive polymers that enhance intracellular drug delivery in vivo. J Control Release 2002; 78: 295-303.

[18] Venugopalan P, Jain S, Sankar S, Singh P, Rawat A, Vyas SP. pHsensitive liposomes: mechanism of triggered release to drug and gene delivery prospects. Pharmazie 2002; 57: 659-71.

[19] Goni FM, Alonso A. Spectroscopic techniques in the study of membrane solubilization, reconstitution and permeabilization by detergents. Biochim Biophys Acta 2000; 1508: 51-68.

[20] Hutchins B. Characterization of plasmids and formulations for nonviral gene therapy. Curr Opin Mol Ther 2000; 2: 131-5.

[21] Sun X, Zhang ZR. Preparation of lipid-protamine-DNA complexes and evaluation of their transfection efficiencies in vitro. Yao Xue Xue Bao 2004; 39: 792-6.

[22] Jin AJ, Huster D, Gawrisch K, Nossal R. Light scattering characterization of extruded lipid vesicles. Eur Biophys J 1999; 28: 187-99.

[23] Turner C, Weir N, Catterall C, Baker TS, Carrington B, Jones MN. The transfection of Jurkat T-leukemic cells by use of $\mathrm{pH}$ sensitive immunoliposomes. J Liposome Res 2002; 12: 311-34.

[24] Pichon C, LeCam E, Guerin B, Coulaud D, Delain E, Midoux P. Poly[Lys-(AEDTP)]: a cationic polymer that allows dissociation of pDNA/cationic polymer complexes in a reductive medium and enhances polyfection. Bioconjug Chem 2002; 13: 76-82.

[25] Ajmani PS, Wang W, Tang F, King MA, Meyer EM, Hughes JA. Transgene delivery with a cationic lipid in the presence of amyloid beta (betaAP) peptide. Neurochem Res 2001; 26: 195-202.

[26] Mehier-Humbert S, Guy RH. Physical methods for gene transfer: improving the kinetics of gene delivery into cells. Adv Drug Deliv Rev 2005; 57: 733-53.

[27] Lin MT, Pulkkinen L, Uitto J, Yoon K. The gene gun: current applications in cutaneous gene therapy. Int J Dermatol 2000; 39: 161-70.

[28] Yang NS, Sun WH. Gene gun and other non-viral approaches for cancer gene therapy. Nat Med 1995; 1: 481-3.

[29] Pertmer TM, Eisenbraun MD, McCabe D, Prayaga SK, Fuller DH, Haynes JR. Gene gun-based nucleic acid immunization: elicitation of humoral and cytotoxic $\mathrm{T}$ lymphocyte responses following epidermal delivery of nanogram quantities of DNA. Vaccine 1995; 13 : 1427-30.

[30] Cui Z, Mumper RJ. Topical immunization using nanoengineered genetic vaccines. J Control Release 2002; 81: 173-84.

[31] Cui Z, Mumper RJ. Chitosan-based nanoparticles for topical genetic immunization. J Control Release 2001; 75: 409-19.

[32] Lowenstein PR. Immunology of viral-vector-mediated gene transfer into the brain: an evolutionary and developmental perspective. Trends Immunol 2002; 23: 23-30.

[33] Felgner PL, Gadek TR, Holm M, et al. Lipofection: a highly efficient, lipid-mediated DNA-transfection procedure. Proc Natl Acad Sci USA 1987; 84: 7413-7.

[34] Ilies MA, Seitz WA, Balaban AT. Cationic lipids in gene delivery: principles, vector design and therapeutical applications. Curr Pharm Des 2002; 8: 2441-73.

[35] Hirko A, Tang F, Hughes JA. Cationic lipid vectors for plasmid DNA delivery. Curr Med Chem 2003; 10: 1185-93.

[36] Singh M, Ugozzoli M, Briones M, Kazzaz J, Soenawan E, O'Hagan DT. The effect of CTAB concentration in cationic PLG microparticles on DNA adsorption and in vivo performance. Pharm Res 2003; 20: 247-51.

[37] Lardans V, Boulo V, Duclermortier P, et al. DNA transfer in a Biomphalaria glabrata embryonic cell line by DOTAP lipofection. Parasitol Res 1996; 82: 574-6.

[38] Behr JP, Demeneix B, Loeffler JP, Perez-Mutul J. Efficient gene transfer into mammalian primary endocrine cells with lipopolyamine-coated DNA. Proc Natl Acad Sci USA 1989; 86: 6982-6.
[39] Hofland HE, Shephard L, Sullivan SM. Formation of stable cationic lipid/DNA complexes for gene transfer. Proc Natl Acad Sci USA 1996; 93: 7305-9.

[40] Mason JT, O'Leary TJ. Effects of headgroup methylation and acyl chain length on the volume of melting of phosphatidylethanolamines. Biophys J 1990; 58: 277-81.

[41] Lasic DD, Papahadjopoulos D. Liposomes revisited. Science 1995; 267: 1275-6.

[42] Belmont P, Aissaoui A, Hauchecorne M, et al. Aminoglycosidederived cationic lipids as efficient vectors for gene transfection in vitro and in vivo. J Gene Med 2002; 4: 517-26.

[43] Ilies MA, Seitz WA, Ghiviriga I, et al. Pyridinium cationic lipids in gene delivery: a structure-activity correlation study. J Med Chem 2004; 47: 3744-54

[44] van der Woude I, Wagenaar A, Meekel AA, et al. Novel pyridinium surfactants for efficient, nontoxic in vitro gene delivery. Proc Natl Acad Sci USA 1997; 94: 1160-5.

[45] Tang F, Hughes JA. Synthesis of a single-tailed cationic lipid and investigation of its transfection. J Control Release 1999; 62: 34558.

[46] Holmen SL, Vanbrocklin MW, Eversole RR, Stapleton SR, Ginsberg LC. Efficient lipid-mediated transfection of DNA into primary rat hepatocytes. In Vitro Cell Dev Biol Anim 1995; 31: 347-51.

[47] Templeton NS, Lasic DD, Frederik PM, Strey HH, Roberts DD, Pavlakis GN. Improved DNA: liposome complexes for increased systemic delivery and gene expression. Nat Biotechnol 1997; 15: 647-52.

[48] Yang K, Mu XS, Hayes RL, et al. DC-Chol liposome-mediated gene transfer in rat spinal cord. Neuroreport 1997; 8: 2355-8.

[49] Kawakami S, Yamashita F, Nishikawa M, Takakura Y, Hashida M. Asialoglycoprotein receptor-mediated gene transfer using novel galactosylated cationic liposomes. Biochem Biophys Res Commun 1998; 252: 78-83.

[50] Bessodes M, Dubertret C, Jaslin G, Scherman D. Synthesis and biological properties of new glycosidic cationic lipids for DNA delivery. Bioorg Med Chem Lett 2000; 10: 1393-5.

[51] Bhattacharya S, Dileep PV. Cationic oxyethylene lipids. Synthesis, aggregation, and transfection properties. Bioconjug Chem 2004; 15: 508-19.

[52] Dileep PV, Antony A, Bhattacharya S. Incorporation of oxyethylene units between hydrocarbon chain and pseudoglyceryl backbone in cationic lipid potentiates gene transfection efficiency in the presence of serum. FEBS Lett 2001; 509: 327-31.

[53] Oupicky D, Carlisle RC, Seymour LW. Triggered intracellular activation of disulfide crosslinked polyelectrolyte gene delivery complexes with extended systemic circulation in vivo. Gene Ther 2001; 8: 713-24.

[54] Ulrich AS. Biophysical aspects of using liposomes as delivery vehicles. Biosci Rep 2002; 22: 129-50.

[55] Sternberg B, Sorgi FL, Huang L. New structures in complex formation between DNA and cationic liposomes visualized by freezefracture electron microscopy. FEBS Lett 1994; 356: 361-6.

[56] Safinya CR. Structures of lipid-DNA complexes: supramolecular assembly and gene delivery. Curr Opin Struct Biol 2001; 11: 440-8.

[57] Xu Y, Szoka FC Jr. Mechanism of DNA release from cationic liposome/DNA complexes used in cell transfection. Biochemistry 1996; 35: 5616-23.

[58] Remy-Kristensen A, Clamme JP, Vuilleumier C, Kuhry JG, Mely Y. Role of endocytosis in the transfection of L929 fibroblasts by polyethylenimine/DNA complexes. Biochim Biophys Acta 2001; 1514: 21-32.

[59] Zabner J, Fasbender AJ, Moninger T, Poellinger KA, Welsh MJ Cellular and molecular barriers to gene transfer by a cationic lipid. J Biol Chem 1995; 270: 18997-9007.

[60] Ellens H, Siegel DP, Alford D, et al. Membrane fusion and inverted phases. Biochemistry 1989; 28: 3692-703.

[61] Siegel DP, Epand RM. The mechanism of lamellar-to-inverted hexagonal phase transitions in phosphatidylethanolamine: implications for membrane fusion mechanisms. Biophys J 1997; 73: 3089111.

[62] Hafez IM, Maurer N, Cullis PR. On the mechanism whereby cationic lipids promote intracellular delivery of polynucleic acids. Gene Ther 2001; 8: 1188-96.

[63] Jordanova A, Lalchev Z, Tenchov B. Formation of monolayers and bilayer foam films from lamellar, inverted hexagonal and cubic lipid phases. Eur Biophys J 2003; 31: 626-32. 
[64] Rappolt M, Hickel A, Bringezu F, Lohner K. Mechanism of the lamellar/inverse hexagonal phase transition examined by high resolution X-ray diffraction. Biophys J 2003; 84: 3111-22.

[65] Ajmani PS, Tang F, Krishnaswami S, Meyer EM, Sumners C, Hughes JA. Enhanced transgene expression in rat brain cell cultures with a disulfide-containing cationic lipid. Neurosci Lett 1999; 277: 141-4.

[66] Hafez IM, Cullis PR. Roles of lipid polymorphism in intracellular delivery. Adv Drug Deliv Rev 2001; 47: 139-48.

[67] Webb MS, Hui SW, Steponkus PL. Dehydration-induced lamellarto-hexagonal-II phase transitions in DOPE/DOPC mixtures. Biochim Biophys Acta 1993; 1145: 93-104.

[68] Smisterova J, Wagenaar A, Stuart MC, et al. Molecular shape of the cationic lipid controls the structure of cationic lipid/dioleylphosphatidylethanolamine-DNA complexes and the efficiency of gene delivery. J Biol Chem 2001; 276: 47615-22.

[69] Koltover I, Salditt T, Radler JO, Safinya CR. An inverted hexagonal phase of cationic liposome-DNA complexes related to DNA release and delivery. Science 1998; 281: 78-81.

[70] Liu F, Liu D. Long-circulating emulsions (oil-in-water) as carriers for lipophilic drugs. Pharm Res 1995; 12: 1060-4.

[71] Frezard F. Liposomes: from biophysics to the design of peptide vaccines. Braz J Med Biol Res 1999; 32: 181-9.

[72] Fatouros DG, Antimisiaris SG. Physicochemical properties of liposomes incorporating hydrochlorothiazide and chlorothiazide. J Drug Target 2001; 9: 61-74.

[73] Peleg-Shulman T, Gibson D, Cohen R, Abra R, Barenholz Y. Characterization of sterically stabilized cisplatin liposomes by nuclear magnetic resonance. Biochim Biophys Acta 2001; 1510: 278-91.

[74] Ollivon M, Lesieur S, Grabielle-Madelmont C, Paternostre M. Vesicle reconstitution from lipid-detergent mixed micelles. Biochim Biophys Acta 2000; 1508: 34-50.

[75] Zuidam NJ, Hirsch-Lerner D, Margulies S, Barenholz Y. Lamellarity of cationic liposomes and mode of preparation of lipoplexes affect transfection efficiency. Biochim Biophys Acta 1999; 1419: 207-20.

[76] Devine DV, Wong K, Serrano K, Chonn A, Cullis PR. Liposomecomplement interactions in rat serum: implications for liposome survival studies. Biochim Biophys Acta 1994; 1191: 43-51.

[77] Liu D, Liu F, Song YK. Recognition and clearance of liposomes containing phosphatidylserine are mediated by serum opsonin. Biochim Biophys Acta 1995; 1235: 140-6.

[78] Liu G, Li D, Pasumarthy MK, et al. Nanoparticles of compacted DNA transfect postmitotic cells. J Biol Chem 2003; 278: 32578-86.

[79] Pante N, Kann M. Nuclear pore complex is able to transport macromolecules with diameters of about $39 \mathrm{~nm}$. Mol Biol Cell 2002; 13: 425-34.

[80] Yoshikawa Y, Yoshikawa K. Diaminoalkanes with an odd number of carbon atoms induce compaction of a single double-stranded DNA chain. FEBS Lett 1995; 361: 277-81.

[81] Xu Y, Hui SW, Frederik P, Szoka FC Jr. Physicochemical characterization and purification of cationic lipoplexes. Biophys J 1999; 77: 341-53.

[82] Felgner JH, Kumar R, Sridhar CN, et al. Enhanced gene delivery and mechanism studies with a novel series of cationic lipid formulations. J Biol Chem 1994; 269: 2550-61.

[83] Ross PC, Hui SW. Lipoplex size is a major determinant of in vitro lipofection efficiency. Gene Ther 1999; 6: 651-9.

[84] Kennedy MT, Pozharski EV, Rakhmanova VA, MacDonald RC. Factors governing the assembly of cationic phospholipid-DNA complexes. Biophys J 2000; 78: 1620-33.

[85] Lee RJ, Huang L. Folate-targeted, anionic liposome-entrapped polylysine-condensed DNA for tumor cell-specific gene transfer. J Biol Chem 1996; 271: 8481-7.

[86] Dauty E, Behr JP, Remy JS. Development of plasmid and oligonucleotide nanometric particles. Gene Ther 2002; 9: 743-8.

[87] Fuchs S, Buethe D, Khanna A, Yadava P, Hughes J. Sulfhydryl based cationic surfactants and the impact of polyanions on disulfide bond formation: implications for gene transfer vectors. J Drug Target 2004; 12: 347-53.

[88] Blessing T, Remy JS, Behr JP. Monomolecular collapse of plasmid DNA into stable virus-like particles. Proc Natl Acad Sci USA 1998; 95: 1427-31.

[89] Liang E, Hughes J. Characterization of a pH-sensitive surfactant, dodecyl-2-(1'-imidazolyl) propionate (DIP), and preliminary stu- dies in liposome mediated gene transfer. Biochim Biophys Acta 1998; 1369: 39-50.

[90] Wang S, Bui V, Hughes JA, King MA, Meyer EM. Adenoassociated virus mediated gene transfer into primary rat brain neuronal and glial cultures: enhancement with the $\mathrm{pH}$-sensitive surfactant dodecyl 2-(1'-imidazolyl) propionate. Neurochem Int 2000; 37: $1-6$.

[91] Koping-Hoggard M, Tubulekas I, Guan H, et al. Chitosan as a nonviral gene delivery system. Structure-property relationships and characteristics compared with polyethylenimine in vitro and after lung administration in vivo. Gene Ther 2001; 8: 1108-21.

[92] De Smedt SC, Demeester J, Hennink WE. Cationic polymer based gene delivery systems. Pharm Res 2000; 17: 113-26.

[93] Boussif O, Lezoualc'h F, Zanta MA, et al. A versatile vector for gene and oligonucleotide transfer into cells in culture and in vivo: polyethylenimine. Proc Natl Acad Sci USA 1995; 92: 7297-301.

[94] Eichman JD, Bielinska AU, Kukowska-Latallo JF, Baker JR Jr. The use of PAMAM dendrimers in the efficient transfer of genetic material into cells 2000; 3: 232-45.

[95] Erbacher P, Zou S, Bettinger T, Steffan AM, Remy JS. Chitosanbased vector/DNA complexes for gene delivery: biophysical characteristics and transfection ability. Pharm Res 1998; 15: 1332-9.

[96] Tang MX, Redemann CT, Szoka FC Jr. In vitro gene delivery by degraded polyamidoamine dendrimers. Bioconjug Chem 1996; 7: 703-14.

[97] Miyata K, Kakizawa Y, Nishiyama N, et al. Block catiomer polyplexes with regulated densities of charge and disulfide crosslinking directed to enhance gene expression. J Am Chem Soc 2004; 126: 2355-61.

[98] Rudolph C, Muller RH, Rosenecker J. Jet nebulization of PEI/DNA polyplexes: physical stability and in vitro gene delivery efficiency. J Gene Med 2002; 4: 66-74.

[99] Petersen H, Merdan T, Kunath K, Fischer D, Kissel T. Poly(ethylenimine-co-L-lactamide-co-succinamide): a biodegradable polyethylenimine derivative with an advantageous $\mathrm{pH}$-dependent hydrolytic degradation for gene delivery. Bioconjug Chem 2002; 13: 812-21.

[100] Godbey WT, Wu KK, Mikos AG. Poly(ethylenimine) and its role in gene delivery. J Control Release 1999; 60: 149-60.

[101] El-Aneed A. An overview of current delivery systems in cancer gene therapy. J Control Release 2004; 94: 1-14.

[102] Allison SA, Herr JC, Schurr JM. Structure of viral phi 29 DNA condensed by simple triamines: a light-scattering and electronmicroscopy study. Biopolymers 1981; 20: 469-88.

[103] Vijayanathan V, Thomas T, Shirahata A, Thomas TJ. DNA condensation by polyamines: a laser light scattering study of structural effects. Biochemistry 2001; 40: 13644-51.

[104] Baeza I, Aguilar L, Santiago R, Ibanez M, Wong C. Electron microscopy and biological properties of pBR322 DNA condensed with the trivalent cations spermidine and hexammine cobalt (III). Rev Latinoam Microbiol 1997; 39: 47-56.

[105] Mislick KA, Baldeschwieler JD. Evidence for the role of proteoglycans in cation-mediated gene transfer. Proc Natl Acad Sci USA 1996; 93: 12349-54.

[106] Ruponen M, Yla-Herttuala S, Urtti A. Interactions of polymeric and liposomal gene delivery systems with extracellular glycosaminoglycans: physicochemical and transfection studies. Biochim Biophys Acta 1999; 1415: 331-41.

[107] Labat-Moleur F, Steffan AM, Brisson C, et al. An electron microscopy study into the mechanism of gene transfer with lipopolyamines. Gene Ther 1996; 3: 1010-7.

[108] Kopatz I, Remy JS, Behr JP. A model for non-viral gene delivery: through syndecan adhesion molecules and powered by actin. $\mathrm{J}$ Gene Med 2004; 6: 769-76.

[109] Gebhart CL, Kabanov AV. Evaluation of polyplexes as gene transfer agents. J Control Release 2001; 73: 401-16.

[110] Kichler A, Leborgne C, Coeytaux E, Danos O. Polyethyleniminemediated gene delivery: a mechanistic study. J Gene Med 2001; 3: 135-44.

[111] Erbacher P, Bettinger T, Belguise-Valladier P, et al. Transfection and physical properties of various saccharide, poly(ethylene glycol), and antibody-derivatized polyethylenimines (PEI). J Gene Med 1999; 1: 210-22.

[112] Wu K, Meyers CA, Bennett JA, King MA, Meyer EM, Hughes JA. Polyethylenimine-mediated NGF gene delivery protects transected septal cholinergic neurons. Brain Res 2004; 1008: 284-7. 
[113] Aberle AM, Tablin F, Zhu J, Walker NJ, Gruenert DC, Nantz MH. A novel tetraester construct that reduces cationic lipid-associated cytotoxicity. Implications for the onset of cytotoxicity. Biochemistry 1998; 37: 6533-40.

[114] Tang F, Hughes JA. Use of dithiodiglycolic acid as a tether for cationic lipids decreases the cytotoxicity and increases transgene expression of plasmid DNA in vitro. Bioconjug Chem 1999; 10: 791-6.

[115] Tang F, Hughes JA. Introduction of a disulfide bond into a cationic lipid enhances transgene expression of plasmid DNA. Biochem Biophys Res Commun 1998; 242: 141-5.

[116] Lim YB, Han SO, Kong HU, et al. Biodegradable polyester, poly[alpha-(4-aminobutyl)-L-glycolic acid], as a non-toxic gene carrier. Pharm Res 2000; 17: 811-6.

[117] Gosselin MA, Guo W, Lee RJ. Efficient gene transfer using reversibly cross-linked low molecular weight polyethylenimine. Bioconjug Chem 2001; 12: 989-94.

[118] Lim YB, Kim SM, Suh H, Park JS. Biodegradable, endosome disruptive, and cationic network-type polymer as a highly efficient and nontoxic gene delivery carrier. Bioconjug Chem 2002; 13: 9527.

[119] Gebhart CL, Sriadibhatla S, Vinogradov S, Lemieux P, Alakhov V, Kabanov AV. Design and formulation of polyplexes based on pluronic-polyethyleneimine conjugates for gene transfer. Bioconjug Chem 2002; 13: 937-44.

[120] Jeon E, Kim HD, Kim JS. Pluronic-grafted poly-(L)-lysine as a new synthetic gene carrier. J Biomed Mater Res A 2003; 66: 854-9.

[121] Nguyen HK, Lemieux P, Vinogradov SV, et al. Evaluation of polyether-polyethyleneimine graft copolymers as gene transfer agents. Gene Ther 2000; 7: 126-38.

[122] Kim EM, Jeong HJ, Park IK, Cho CS, Bom HS, Kim CG. Monitoring the effect of PEGylation on polyethylenimine in vivo using nuclear imaging technique. Nucl Med Biol 2004; 31: 781-4.

[123] Kichler A. Gene transfer with modified polyethylenimines. J Gene Med 2004; 6(Suppl 1): S3-10.

[124] Awasthi VD, Garcia D, Goins BA, Phillips WT. Circulation and biodistribution profiles of long-circulating PEG-liposomes of various sizes in rabbits. Int J Pharm 2003; 253: 121-32.

[125] Cattel L, Ceruti M, Dosio F. From conventional to stealth liposomes: a new frontier in cancer chemotherapy. Tumori 2003; 89: 237-49.

[126] Gabizon AA. Stealth liposomes and tumor targeting: one step further in the quest for the magic bullet. Clin Cancer Res 2001; 7: 223-5.

[127] Kim ES, Lu C, Khuri FR, et al. A phase II study of STEALTH cisplatin (SPI-77) in patients with advanced non-small cell lung cancer. Lung Cancer 2001; 34: 427-32.

[128] Koukourakis MI, Koukouraki S, Giatromanolaki A, et al. High intratumoral accumulation of stealth liposomal doxorubicin in sarcomas--rationale for combination with radiotherapy. Acta Oncol 2000; 39: 207-11.
[129] Takeuchi H, Kojima H, Yamamoto H, Kawashima Y. Evaluation of circulation profiles of liposomes coated with hydrophilic polymers having different molecular weights in rats. J Control Release 2001; 75: 83-91.

[130] Yu RZ, Geary RS, Leeds JM, et al. Pharmacokinetics and tissue disposition in monkeys of an antisense oligonucleotide inhibitor of Ha-ras encapsulated in stealth liposomes. Pharm Res 1999; 16: 1309-15.

[131] Kommareddy S, Tiwari SB, Amiji MM. Long-circulating polymeric nanovectors for tumor-selective gene delivery. Technol Cancer Res Treat 2005; 4: 615-25.

[132] Lee M, Kim SW. Polyethylene glycol-conjugated copolymers for plasmid DNA delivery. Pharm Res 2005; 22: 1-10.

[133] van Steenis JH, van Maarseveen EM, Verbaan FJ, et al. Preparation and characterization of folate-targeted pEG-coated pDMAEMAbased polyplexes. J Control Release 2003; 87: 167-76.

[134] Sung SJ, Min SH, Cho KY, et al. Effect of polyethylene glycol on gene delivery of polyethylenimine. Biol Pharm Bull 2003; 26: 492 500 .

[135] Mishra S, Webster P, Davis ME. PEGylation significantly affects cellular uptake and intracellular trafficking of non-viral gene delivery particles. Eur J Cell Biol 2004; 83: 97-111.

[136] Ogris M, Walker G, Blessing T, Kircheis R, Wolschek M, Wagner E. Tumor-targeted gene therapy: strategies for the preparation of ligand-polyethylene glycol-polyethylenimine/DNA complexes. J Control Release 2003; 91: 173-81.

[137] Kircheis R, Schuller S, Brunner S, et al. Polycation-based DNA complexes for tumor-targeted gene delivery in vivo. J Gene Med 1999; 1: 111-20.

[138] Labhasetwar V. Nanotechnology for drug and gene therapy: the importance of understanding molecular mechanisms of delivery. Curr Opin Biotechnol 2005; 16: 674-80

[139] Nori A, Jensen KD, Tijerina M, Kopeckova P, Kopecek J. Tatconjugated synthetic macromolecules facilitate cytoplasmic drug delivery to human ovarian carcinoma cells. Bioconjug Chem 2003; 14: 44-50.

[140] Lundberg P, Langel U. A brief introduction to cell-penetrating peptides. J Mol Recognit 2003; 16: 227-33.

[141] Nettelbeck DM, Jerome V, Muller R. Gene therapy: designer promoters for tumour targeting. Trends Genet 2000; 16: 174-81.

[142] Liu G, Molas M, Grossmann GA, et al. Biological properties of poly-L-lysine-DNA complexes generated by cooperative binding of the polycation. J Biol Chem 2001; 276: 34379-87.

[143] Wagner E, Ogris M, Zauner W. Polylysine-based transfection systems utilizing receptor-mediated delivery. Adv Drug Deliv Rev 1998; 30: 97-113.

[144] Bielinska AU, Chen C, Johnson J, Baker JR Jr. DNA complexing with polyamidoamine dendrimers: implications for transfection. Bioconjug Chem 1999; 10: 843-50. 